JKM (Jurnal Kebidanan Malahayati),Vol 7,No.4.Oktober 2021,

ISSN (Print) 2476-8944 ISSN (Online) 2579-762X, Hal 647-651

\title{
DAUN KATUK MEMPENGARUHI PRODUKSI ASI PADA IBU MENYUSUI
}

\author{
Citra Erlanda ${ }^{1}$, Nita Evrianasari ${ }^{*}$, Susilawati ${ }^{3}$, Neneng Siti Lathifah ${ }^{4}$ \\ 1,2,3,4Program DIV Kebidanan Universitas Malahayati \\ *Korespondensi E-mail : nita.nuninosa@gmail.com
}

\section{ABSTRACT KATUK LEAF EXTRACT AFFECTS BREAST MILK PRODUCTION IN BREASTFEEDING MOTHERS}

Background Milk production which is not quite the most common factors that lead to the cessation of the practice of exclusive breastfeeding type in an attempt to increase the rate of secretion and milk production is through the use of traditional herb medicine such as leaf extract katuk S leaves katuk been shown to have a wide variety of non-pharmacological activity. And katuk contains a number of important nutrients such as protein, vitamin $C$, vitamin $D$, calcium to folic acid.

The purpose of this research is to determine the effect of giving Katuk leaf extract on breast milk production of breastfeeding mothers at Kemiling Inpatient Health Center Bandar Lampung 2021.

Method research design using pre-experimental method with two group pretest - posttest approach. sampling technique with purposive sampling as many as 30 breastfeeding mothers, the results of the study were analyzed by independent t-test. This data was taken using an observation sheet in the form of a checklist for the consumption of katuk leaves extract that was consumed by the mother. This research was conducted in MarchJuly 2021.

The results of statistical tests using independent obtained p-value $0.001<0.05$, it can be concluded that there is a significant difference between giving katuk leaf extract and not giving katuk leaf extract.

Conclusion The results of statistical test using independent $t$-test obtained $p$-value $0.001<0.05$, it can be concluded that there is a significant difference between giving katuk leaves extract and not giving katuk leaves extract.

Suggestion Future researchers are expected to use this research source as an additional reference. Further research on the effect of katuk leaf extract on breast milk production by adding other herbal ingredients in accordance with the prescribed dose

Keywords: Katuk Leaves Extract, ASI

\section{ABSTRAK}

Latar Belakang Produksi ASI yang tidak cukup merupakan faktor penghambat yang paling umum menyebabkan berhentinya praktik pemberian ASI eksklusif ketik salah satu upaya meningkatkan laju sekresi dan produksi ASI adalah melalui penggunaan obat ramuan tradisional seperti ekstrak daun katuk $\mathrm{S}$ daun katuk telah terbukti memiliki berbagai macam aktivitas nonfarmakologi. Dan katuk mengandung sejumlah nutrisi penting seperti protein, vitamin $C$, vitamin $D$, kalsium hingga asam folat.

Tujuan penelitian ini adalah untuk mengetahui Pengaruh Pemberian Ekstrak Daun Katuk Terhadap Produksi ASI Pada Ibu Menyusui Di Puskesmas Rawat

Inap Kemiling Bandar Lampung 2021

Metode penelitian Desain penelitian menggunakan metode Pra Eksperimental dengan pendekatan two grouppretest - posttest. teknik pengambilan sampel dengan purposive sampling sebanyak 30 orang ibu menyusui, hasil penelitian dianalisa dengan uji independent $t$ - test. Penelitian ini dilaksanakan pada bulan maretjuli 2021.

Hasil uji statistik menggunakan independen didapat nilai $p$-value $0,001<0,05$ maka dapat disimpulkan bahwa ada perbedaan yang signifik antara pemberian ektrak daun katuk dan yang tidak diberikan ektrak daun katuk

Kesimpulan Hasil uji statistik didapatkan nilai $p<0,05$ sehingga dapat disimpulkan Ha dierima yang artinya ada pengaruh pemberian ektrak daun katuk terhadap ibu menyusui menyusui Di Puskesmas Rawat Inap Kemiling Bandar Lampung 2021. 


\section{Citra Erlanda, Nita Evrianasari, Susilawati, Neneng Siti Lathifah}

Saran untuk Peneliti selanjutnya diharapkan dapat menggunakan sumber penelitian ini sebagai referensi tambahan. Penelitian lebih lanjut tentang pengaruh ekstrak daun katuk terhadap produksi ASI dengan menambahan bahan herbal lainnya sesuai dengan dosis yang ditentukan

Kata Kunci : Ekstrak Daun Katuk,ASI

\section{PENDAHULUAN}

Pemberian ASI sangat penting bagi tumbuh kembang yang optimal baik fisik maupun mental dan kecerdasan bayi. Pemberian ASI eksklusif perlu mendapat perhatian para ibu, keluarga, masyarakat dan tenaga kesehatan agar proses menyusui dapat terlaksana dengan benar. Cara pemberian makanan pada bayi yang baik dan benar adalah menyusui bayi secara eksklusif sejak lahir sampai dengan umur 6 bulan dan meneruskan menyusui anak sampai umur 24 bulan. Mulai umur 6 bulan, bayi mendapat makanan pendamping ASI yang bergizi sesuai dengan kebutuhan tumbuh kembangnya (Kemenkes RI, 2013)

ASI merupakan suatu emulsi lemak dalam larutan protein, laktose dan garam-garam organik yang disekresi oleh kedua belah kelenjar payudara dan sebagai makanan utama bagi bayi. Komposisinya sesuai untuk pertumbuhan dan perkembangan bayi yang berubah sesuai dengan kebutuhan bayi pada setiap saat, ASI juga mengandung zat pelindung yang dapat menghindari bayi dari berbagai penyakit infeksi. Pemberian ASI juga mempunyai pengaruh emosional yang luar biasa yang mempengaruhi hubungan batin ibu dan anak serta perkembangan jiwa si anak (Maryunani, 2015)

ASI (Air Susu Ibu) adalah makanan terbaik bagi bayi. Kecukupan ASI penting untuk tumbuh kembang bayi. Produksi Asi yang tidak cukup merupakan faktor penghambat yang paling umum menyebabkan berhentinya praktik pemberian ASI eksklusif. Salah satu upaya meningkatkan laju sekresi dan produksi ASI adalah melalui penggunaan ramuan tradisional seperti rebusan dan ekstrak daun katuk. (Endang Suwanti,Kuswati

2015)

Daun katuk mengandung polifenil dan steroid yang berperan dalam reflex prolaktin atau merangsang alveoli untuk memproduksi ASI, serta merangsang hormon oksitosin untuk memacu pengeluaran dan pengaliran ASI dapat memperlancar pengeluaran ASI. (Endang Suwanti,Kuswati 2015) daun papaya dan sebagainya. (Endang Suwanti,Kuswati 2015)

Daun katuk mengandung hampir $7 \%$ protein dan $19 \%$ serat kasar, vitamin $\mathrm{K}$, prokarotin -vitamin A. Vitmin B dan C. Mineral yang dikandung adalah Kalsium (2,8\%) zat besi, kalium, fisfor dan magnesium. Perlu diketahui bahwa daun katuk ini juga mengandung papaverina, yaitu suatu alkaloid yang juga terdapat pada candu (opium). Konsumsi yang berlebihan dapat menyebabkan efek samping seperti keracunan papaverina. Warna daun katuk yang hijau gelap menunjukkan kadar klorofil yang tinggi. Daun katuk mempunyai sifat yang khas yaitu manis, mendinginkan dan membersihkan darah, khasiat antipiretik dan laktagog (Suwanti, Endang.2015.)

\section{METODE PENELITIAN}

Jenis Penelitian ini Penelitian ini menggunakan jenis penelitian kuantitatif yaitu penelitian yang datanya berupa angka-angka (score, nilai) dan dianalisis dengan analisa statistic. Penelitian ini bertujuan untuk mengetahui pengaruh pemberian ekstrak daun katuk pada ibu menyusui bayi $0-6$ bulan di puskesmas rawat inap kemiling bandar lampung tahun 2021.

\section{HASIL DAN PEMBAHASAN \\ Uji Normalitas}

Salah satu upaya memperbanyak ASI, adalah meningkatkan kualitas makanan yang berpengaruh secara langsung pada produksi air susu, misalnya sayur-sayuran hijau, daun katuk, daun ubi jalar, Hasil uji normalitas $p$-value pada kelompok intervensi pre intervensi 0,119 post intervensi 0,469 pada kelompok kontrol pre kontrol 0,784 post kontrol 0,819. Keseluruhan $p$ value $>0.05$ yang artinya data berdistribusi normal, dan selanjutnya dapat dilakukan uji t-tst 
JKM (Jurnal Kebidanan Malahayati),Vol 7,No.4.Oktober 2021,

ISSN (Print) 2476-8944 ISSN (Online) 2579-762X, Hal 647-651

Tabel 1.

Hasil Uji Normalitas Variable Sebelum Dan Sesudah Diberikan Perlakuan Ekstrak Daun katuk

\begin{tabular}{lcc}
\hline Pengukuran produksi ASI & \multicolumn{2}{c}{$p$-value } \\
\hline \multirow{2}{*}{ Kelompok intervensi } & Pre intervensi & 0,119 \\
& Post intervensi & 0,469 \\
\multirow{2}{*}{ Kelompok kontrol } & Pre control & 0,784 \\
& Post control & 0,819 \\
\hline
\end{tabular}

Tabel 2.

Kelancaraan Produksi ASI Pada Ibu Menyusui Sesbelum dan Sesudah Dilakukan Intervensi Ekstrak Daun Katuk Di Wilayah Kerja Puskesmas Rawat Inap Kemiling Tahun 2021

\begin{tabular}{lccc}
\hline \multicolumn{1}{c}{ Kelancaraan produksi ASI dengan BB } & Mean & Median & Std.deviasi \\
\hline Pre intervensi & 3360,00 & 3400,00 & 358,170 \\
Post intervensi & 3766,67 & 3800,00 & 386,683 \\
\hline
\end{tabular}

Pada tabel 2 dapat diketahui hasil pre intervensi 3766,67 gram median 3800,00 gram gram 386,683 std.deviasi 358,170 post intervensi std.deviasi mean 3360,00 gram median 3400,00

Tabel 3.

Kelancaraan Produksi Asi Pada Ibu Menyusui Yang Tidak Diberikan Intervensi Ekstrak Daun Katuk Pre Kontrol Post Kontrol Di Wilayah Kerja Puskesmas Rawat Inap Kemiling Tahun 2021

\begin{tabular}{lccc}
\hline Kelancaraan produksi ASI dengan BB & Mean & Median & Std.deviasi \\
\hline Pre kontrol & 3073,33 & 3000,00 & 347,371 \\
Post kontrol & 3286,67 & 3300,00 & 272,204 \\
\hline
\end{tabular}

Pada tabel 3 dapat diketahui hasil pre kontrol mean 3073,33gram median 3000,00 gram std.deviasi $347,371 \mathrm{gram}$ post kontrol mean $3286,67 \mathrm{gram}$ median 3300,00 gram std.deviasi 272,204

\section{PEMBAHASAN}

Hasil uji statistik menggunakan independen didapat nilai $p$-value $0,001<0,05$ maka dapat disimpulkan bahwa ada efektivitas pengaruh pemberian ekstrak daun katuk pada ibu menyusui diwilayah Kerja Rawat Inap Kemiling Bandar Lampung Tahun 2021

Penelitian ini sejalan dengan penelitian yang dilakukan dengan Peneliti Endang Suwanti, kuswanti (2015) dengan Pengaruh konsumsi ekstrak daun katuk terhadap kecukupan ASI pada ibu menyusui di klaten. Hasil penelitian adalah pada kelompok perlakuan sebelum mengkonsumsi daun katuk 53,3 \% ASI cukup dan setelah konsumsi katuk 70\% ASI lebih. Sedangkan pada kelompok kontrol pada observasi sebelum 53\% ASI cukup dan sesudah satu bulan kemudian $37 \%$ ASI cukup , $30 \%$ ASI lebih . Pada analisis statistik uji pengaruh chi square diperoleh hasil nila $p=0,002$.
Kesimpulan: Ada pengaruh yang signifikan konsumsi ekstrak daun katu terhadap kecukupan ASI $(p=0,000)$

Berbagai penelitian telah dilakukan untuk mengetahui komposisi yang terdapat di dalam tanaman katuk. Berdasarkan hasil analisa diketahui bahwa pada tiap $100 \mathrm{~g}$ daun katuk mentah mengandung 59 kal., $4,8 \mathrm{~g}$ protein, $1 \mathrm{~g}$ lemak, $11 \mathrm{~g}$ karbohidrat, $204 \mathrm{mg}$ kalsium, $83 \mathrm{mg}$ fosfor, $2,7 \mathrm{mg}$ besi, $103.705 \mathrm{SI}$ vitamin A, 0,1 mg vitamin D, 239 $\mathrm{mg}$ vitamin $\mathrm{C}$ dan air $81 \mathrm{~g}$. Kemudaian pada penapisan fitokimia daun katuk mengandung sterol, alkaloid, flanofoid, dan tanin (Ferasyi, 2010; Namirah, nasution A.2018)

Daun katuk mengandung polifenol dan steroid yang berperan dalam reflekprolaktin atau merangsang alveoli untuk memproduksi ASI, serta merangsang hormon oksitosin untuk memacu pengeluaran dan pengaliran ASI dapat mempelajari pengeluaran ASI daun katuk juga mengandung beberapa senyawa Alifa titik-titik khasiat daun katuk sebagai peningkatan produksi ASI, diduga berasal dari efek hormonal senyawa kimia yang bersifat ekstrogenik (Triananinsi,Nurhidayat et all. 2015). Hubungan Pemberian Sayur Daun Katuk 
Terhadap Kelancaran ASI Pada Ibu Multipara Di Puskesmas Caile)

Berdasarkan hasil analisa diketahui bahwa pada tiap $100 \mathrm{~g}$ daun katuk mentah mengandung 59 kal., 4,8 g protein, $1 \mathrm{~g}$ lemak, $11 \mathrm{~g}$ karbohidrat, 204 $\mathrm{mg}$ kalsium, $83 \mathrm{mg}$ fosfor, $2,7 \mathrm{mg}$ besi, $103.705 \mathrm{SI}$ vitamin $A, 0,1 \mathrm{mg}$ vitamin $\mathrm{D}, 239 \mathrm{mg}$ vitamin $C$ dan air $81 \mathrm{~g}$. Kemudaian pada penapisan fitokimia daun katuk mengandung sterol, alkaloid, flanofoid, dan tanin (Ferasyi, 2010; Namirah,nasution A.2018) Menurut peneliti, produksi ASI dapat dipengaruhi oleh beberapa hal, seperti frekuensi memberikan ASI, makanan yang dikonsumsi hingga pola istirahat, kandungan gizi pada ekstrak daun katuk dapat meningkatkan kelancaran ASI ibu, hal tersebut dapat dilihat dari peningkatan rata-rata sebelum dan sesudah diberikan ektrak daun katuk dengan 3360 gram sebelum diberikan ekstrak daun katuk 3766 gram sesudah diberikan ekstrak daun katuk. Menurut Penelitian Putu Sukma Pratiwi Sutama,Luh Dkk Tahun 2015 Tentang Hubungan Pekerjaan, Paritas, Dan Keterampilan Perawatan Payudara Dengan Perilaku Pemberian Asi Eksklusif didapatkan bahwa adanya hubungan antara paritas dengan perilaku pemberian ASI eksklusif. Ibu yang sudah pernah melahirkan akan memberikan laktasi kedua yang lebih baik dibanding ketika laktasi pertama, hal ini berhubungan dengan sudah adanya pengalaman pada laktasi kedua, akan tetapi ada kemungkinan bahwa ibu yang sudah pernah menyusui tidak memberi ASI eksklusif. Hal ini biasanya disebabkan oleh kurangnya motivasi, ibu yang bekerja dan lain-lain yang membuat pemberian susu formula lebih disukai karena lebih praktis. Hasil analisis univariat paritas ibu di wilayah kerja Puskesmas Pekapuran Raya menunjukkan bahwa ibu dengan riwayatmultiparitas (52\%) lebih banyak dibanding ibu dengan riwayat primiparitas $(46 \%)$ dan grandeparitas $(2 \%)$. Hasil penelitian ini sesuai dengan penelitian yang dilakukan Mododahi dkk pada tahun 2018 di Kepulauan Sangihe yang menunjukkan bahwa tingginya angka ibu dengan riwayat multiparitas lebih banyak daripada ibu dengan riwayat primiparitas

Menurut Penelitian Welis,Gemilang Surya Tahun 2020 Tentang Hubungan Usia, Pendidikan, Dan Pekerjaandengan Pemberian Asi Eksklusif. Pada variabel usia terdapat dalam dua artikel, variabel usia (Meiyana,2010) dibagi menjadi dua kategori yaitu $<20-30$ tahun dan $>30$ tahun. Pada kategori $<20-30$ tahun sebanyak $17 \quad(32,7 \%)$ responden melakukan pemberian ASI eksklusif, sedangkan pada kategori $>30$ tahun sebanyak 16 $(57,1 \%)$ responden melakukanpemberian ASI eksklusif. Hasil uji statistik didapat $p$ value 0,034 (p
$<0,05)$ maka dapat disimpulkan terdapat hubungan antara usia dengan pemberian ASI eksklusif (Meiyana, 2010). Pada penelitian (Happy, 2018) variabel usia dibagi menjadi dua kategori yaitu $\leq 35$ tahun kategori usia reproduktif dan $>35$ tahun kategori usia non reproduktif. Pada kategori $\leq 35$ tahun sebanyak $53(76,8 \%)$ responden melakukan pemberian ASI eksklusif, sedangkan pada kategori $>35$ tahun sebanyak $5(50 \%)$ responden melakukan pemberian ASI eksklusif. Hasil uji statistik didapat $p$ value $0,120(p<0,05)$ maka dapat disimpulkan terdapat hubungan antara usia dengan pemberian ASI eksklusif (Happy, 2018). Usia yang kurang dari 20 tahun dianggap masih belum matang secara fisik mental dan psikologi dalam menghadapi kehamilan, persalinan serta pemberian ASI, semakin muda usia ibu maka bayi cenderung semakin untuk tidak diberikan ASI Eksklusif karena tuntutan sosial, kejiwaan ibu dan tekanan sosial yang dapat mempengaruhi produksi ASI. Usia yang kurang dari 20 tahun merupakan masa pertumbuhan termasuk organ reproduksi (payudara), sedangkan usia lebih dari 35 tahun organ reproduksi sudah lemah dan tidak optimal dalam pemberian ASI Ekslusif, sehingga kemampuan seorang ibu untuk menyusui secara eksklusif juga sudah tidak optimal lagi karena penurunan fungsi dari organ reproduksi seperti payudara (Hidayati, 2012).

Pada penelitian ini terjadi kenaikan yang signifikan dari produksi ASI ssebelum dan ASI sesudah, peningkatan antara kenaikan berat badan pada hasil sebelum dilakukan intervensi, menurut peneliti kandungan senyawa yang terkandung dalam ektrak daun katuk memiliki potensi dalam menstimulasi hormon oksitosin dan prolaktin seperti alkaloid, polifenol, steroid, flavonoid dan substansi lainnya paling efektif dalam meningkatkan dan memperlancar produksi ASI.

\section{SIMPULAN}

Ada pengaruh pemberian ekstrak daun katuk pada ibu menyusui diwilayah Kerja Rawat Inap Kemiling Bandar Lampung Tahun 2021

\section{SARAN}

Diharapkan untuk ibu menyusui agar dapat memanfaatkan konsumsi ekstrak daun katuk sebagai alternatif non farmakologi dengan dosis 250 gram diminum 3 kali sehari selama 2 minggu untuk memperlancar produksi ASI, karena ASI adalah makan penting bagi bayi, dan sebaikya ibu memberikan ASI eksklusif sejak 0-6 bulan tanpa diberi makanan tambahan, dan dinlanjutkan hingga usia 2 tahun didampingi dengan makanan tambahan untuk anak. 
JKM (Jurnal Kebidanan Malahayati),Vol 7,No.4.Oktober 2021,

ISSN (Print) 2476-8944 ISSN (Online) 2579-762X, Hal 647-651

\section{DAFTAR PUSTAKA}

Anggraini,Yetti.(2010). Asuhan Kebidanan Masa Nifas. Yogyakarta : Pustaka Rihama

Dewi,Lia. (2011). Asuhan Kebidanan Pada Ibu Nifas. Yogyakarta:Pustaka Baru Pres

Gemilang, S. W., \& Werdani, K. E. (2020). Hubungan Usia, Pendidikan, dan Pekerjaan dengan Pemberian Asi Eksklusif (Doctoral dissertation, Universitas Muhammadiyah Surakarta).

Juliastuti, J. (2019). Efektivitas Daun Katuk (Sauropus Androgynus) Terhadap Kecukupan Asi Pada Ibu Menyusui Di Puskesmas Kuta Baro Aceh Besar. Indonesian Journal for Health Sciences, 3(1), 1-5.

Maryunani, Anik. (2015). Inisiasi Menyusu Dini Asi Eksklusif Dan Manajemen Laktasi. Jakarta: Trans Info Media.

Mawaddah, S., \& Karlawaty, N. (2021). Efektivitas Teh Daun Katuk terhadap Produksi ASI pada Ibu Postpartum Hari ke 4-7. Jurnal Surya Medika (JSM), 6(2), 167-171.

Notoatmodjo, Soekidjo.2018.Metodologi Penelitian Kesehatan.Jakarta: PT Rineka Cipta

ProfilKemenkes RI . (2013). Cakupan ASI Dan Inisiasi Menyusu Dinii
ProfilKemenkes RI. ( 2017) Cakupan ASI Dan Inisiasi Menyusu Dinii

ProfilKemenkes RI. (2018) Cakupan ASI Dan Inisiasi Menyusu Dinii

Rukiyyah,Ali R dkk. (2011). Asuhan Kebidanan III. Jakarta : PT Agromedia Pustaka

Salleha,Sitti. (2011). Asuhan Kebidanan Pada Ibu Nifas. Yogyakarta: Pustaka Belajar

Suwanti, E., \& Kuswati, K. (2016). Pengaruh Konsumsi Ekstrak Daun Katuk Terhadap Kecukupan Asi Pada Ibu Menyusui Di Klaten. Interest: Jurnal IImu Kesehatan, 5(2), 132-135.

Sutama, L. P. S. P., Arifin, S., \& Yuliana, I. (2020). Hubungan Pekerjaan, Paritas, dan Keterampilan Perawatan Payudara dengan Perilaku Pemberian ASI Eksklusif. Homeostasis, 3(3), 385-394.

Triananinsi, N., Andryani, Z. Y., \& Basri, F. (2020). Hubungan Pemberian Sayur Daun Katuk Terhadap Kelancaran ASI Pada Ibu Multipara Di Puskesmas Caile. Journal of Healthcare Technology and Medicine, 6(1), 12-20.

World Health Organization (WHO), 2010

Wulandari,Setyo R.(2011) . Asuhan Kebidanan Ibu Masa Nifas. Yogyakarta: Gosyen Publlishing

Yanti,Dama. (2011). Asuhan Kebidanan Masa Nifas. Yogyakarta : Diva Press 